\title{
Combining Ability of Yield and Yield Components in Eggplant (Solanum melongena L.) During Summer
}

\author{
M. Sharaf Uddin ${ }^{1, *}$, M.M. Rahman', M.M. Hossain ${ }^{2}$, M.A. Khaleque Mian ${ }^{3}$ \\ ${ }^{1}$ Department of Agroforestry and Environmental Science, Sylhet Agricultural University, Bangladesh \\ ${ }^{2}$ Department of Horticulture, BSMRAU, Bangladesh \\ ${ }^{3}$ Department of Genetics and Plant Breeding, BSMRAU, Bangladesh
}

Copyright $(\subset 2015$ by authors, all rights reserved. Authors agree that this article remains permanently open access under the terms of the Creative Commons Attribution License 4.0 International License.

\begin{abstract}
Combining ability in eighteen eggplant genotypes were studied at Bangabandhu Sheikh Mujibur Rahman Agricultural University (BSMRAU), Gazipur, Bangladesh during March 2007 to September 2009. Eggplant genotypes were evaluated for different quantitative characters. Highly significant variances due to general combining ability (GCA) and specific combining ability (SCA) for all the studied characters indicated the importance of both additive and non-additive gene actions. The predominance of additive gene action was found for most of the studied characters. Considering GCA effects, the parents $\mathrm{P}_{1}, \mathrm{P}_{2}$ and $\mathrm{P}_{6}$ were the good general combiner for number of fruits per plant and yield per plant; $\mathrm{P}_{3}, \mathrm{P}_{5}$ and $\mathrm{P}_{8}$ for fruit weight; $\mathrm{P}_{4}$ for fruit length and $\mathrm{P}_{3}$ and $\mathrm{P}_{8}$ for fruit breadth and $\mathrm{P}_{1}$, $\mathrm{P}_{6}, \mathrm{P}_{2}$ and $\mathrm{P}_{7}$ for yield per plant. Considering SCA effects, the crosses $\mathrm{P}_{5} \times \mathrm{P}_{7}$ were important for fruit length, fruit weight, number of fruits and yield per plant; $\mathrm{P}_{5} \times \mathrm{P}_{8}$ for fruit breadth, fruit weight, and yield per plant; $\mathrm{P}_{1} \times \mathrm{P}_{6}$ and $\mathrm{P}_{2} \times \mathrm{P}_{7}$ for fruit breadth, number of fruit and yield per plant; $\mathrm{P}_{1} \times \mathrm{P}_{6}, \mathrm{P}_{2} \times \mathrm{P}_{7}, \mathrm{P}_{4}$ $\mathrm{x}_{7}$ and $\mathrm{P}_{5} \times \mathrm{P}_{7}$ for number of fruits and yield per plant.
\end{abstract}

Keywords Combining Ability, Eggplant, Genotype, Summer, Yield

\section{Introduction}

Eggplant (Solanum melongena L.) is one of the most important vegetable which can contribute a substantial amount in the lean period of Bangladesh. Combining ability of eggplant was studied by several workers in India [13,14]). In order to select superior parents, it is imperative to study the relative ability of the parents to transfer economic traits in the hybrid combination. Combining ability is one of the important and powerful tools in identifying the best combiner that may be used in crosses to exploit heterosis. It helps to know the genetic architecture of various characters that enables the breeder to design effective breeding plan for future improvement of the existing materials. This information is also useful to the breeder for selection of diverse parents and hybrid combinations. It is possible to develop high yielding variety through genetic manipulation and selection of superior parents. Hence, it is necessary to have knowledge about genetic make up of yield and yield contributing characters. Although eggplant is the major vegetable in Bangladesh, yet an organized and systematic attention has not been given for its improvement from a breeding point of view, particularly for summer and summer rainy season production. There is little information in this regard during winter studied by Rashid et al.[11], Rahman[10] and Saha et al.[12], but information during hot humid condition is meager. Considering the above facts the present study was undertaken to determine the GCA of the selected parents and SCA of crosses and to generate information on the nature and magnitude of some gene actions involved in the inheritance of yield and yield contributing characters.

\section{Materials and Methods}

The present study was carried out at the experimental field of Bangabandhu Sheikh Mujibur Rahman Agricultural University (BSMRAU), Gazipur, Bangladesh during March 2007 to September 2008. Eight diverse parental genotypes of eggplant were selected for summer cultivation based on morphological characterization and diversity study. Eight parents and $28 \mathrm{~F}_{1}$ hybrids produced from those parents were used as plant materials for the study. The salient features of the selected genotypes are presented in table 1 . The selected eight genotypes were grown in summer 2007 for crossing in a half diallel fashion. For effective pollination and fertilization, the flower buds which just changed their color from green to purplish white and about to bloom next day were selected. Emasculation and pollination were done in the same day during 7.30-11.00 a.m. The pollinated flowers were bagged with butter paper and tagged along with necessary information. After complete maturity, some fruits from eight selfed parents and 28 $\mathrm{F}_{1}$ crosses were harvested for obtaining the parental and $\mathrm{F}_{1}$ 
hybrid seeds. Then the seeds of parents and $\mathrm{F}_{1} \mathrm{~s}$ were collected, air dried and preserved in desiccators with proper label and used for the study in the next season. Seeds of the selected parents and $F_{1}$ hybrids were sown on the tray on March 142008 and after necessary hardening, the seedlings were transplanted in the main field on April 20 2008. The experiment was laid out in a randomized complete block design with 3 replications. Ten seedlings were planted in a unit plot with a plant spacing of $70 \mathrm{~cm}$ apart in single row maintaining $50 \mathrm{~cm}$ drain between the plots. Twenty eight $F_{1}$ hybrids along with their selected parental lines were grown for studying the combining ability. Yield and yield contributing characters were used for this study. Observations were made on days to $1^{\text {st }}$ fruit harvesting, fruit length, fruit diameter, individual fruit weight, number of fruits per plant and yield per plant. The collected data were subjected to combining ability analysis following Model I and Method 2 (half diallel fashion) of Griffing [3]. Griffing's analysis [4] was intended to determine the performance of the parents and their relative contribution to the $F_{1}$ 's as determined by general and specific combining ability (GCA and SCA) effects. The calculation of combining ability was performed from the following formula:

$$
\mathrm{Xijk}=\mu+\mathrm{gi}+\mathrm{gj}+\mathrm{sij}+\mathrm{eijk}
$$

Where, Xijk is the genotype score, $\mu$ is the overall mean of the experiment, so that all other scores are expressed as deviations from this mean, gi is the GCA effects of the ith parent, gi is the GCA effects of the jth parent, sij SCA of the hybrid, eijk is the error deviation of the particular plot.

For the calculation of GCA of the parents and SCA of the hybrids, the mean was calculated over blocks and GCA and SCA were estimated from the means. Each column (or row) represented entries with one parent in common and crossed to all other parents including self. This column was referred as an array. The GCA of any parent was estimated as the difference between its array mean and the overall mean.

Similarly, SCAs of the hybrids was also calculated as:

$$
\mathrm{Sij}=\mathrm{X}-(\mu+\mathrm{gi}+\mathrm{gj})
$$

Where, $X$ is the score of the hybrid between the ith and $\mathrm{jth}$ parents and the other terms are defined as above.

\begin{tabular}{|c|c|c|c|c|}
\hline Genotype & Identity & $\begin{array}{c}\text { Place of } \\
\text { collection }\end{array}$ & $\begin{array}{l}\text { Parent } \\
\text { symbol }\end{array}$ & Main features/Characteristics \\
\hline SM001 & $\begin{array}{l}\text { BARI } \\
\text { Begun-4 } \\
\text { (Kazla) }\end{array}$ & HRC, BARI & $\mathrm{P}_{1}$ & $\begin{array}{l}\text { Fruit is long, slight curved and deep purple uniform color. Plant height is medium } \\
\text { with prostrate growth habit and moderately spreading purplish look. Flower light } \\
\text { violet color with early flowering habit. Fruit position on the plant is pendant. } \\
\text { Average fruit weight is } 26.01 \mathrm{~g} \text {, number of fruit per plant is } 32.17 \text { and yield/plant is } \\
828.85 \mathrm{~g}\end{array}$ \\
\hline SM002 & Bottle & Tangail & $\mathrm{P}_{2}$ & $\begin{array}{l}\text { Fruit is oblong, straight and purple uniform color. Plant is medium height with } \\
\text { prostrate growth habit and moderately spreading purplish look. Flower light violet } \\
\text { color. Fruit position on the plant is pendant. Average fruit weight is } 26.38 \mathrm{~g} \text {, fruits } \\
\text { per plant is } 31.93 \text { and yield/plant is } 865.47 \mathrm{~g}\end{array}$ \\
\hline SM004 & $\begin{array}{c}\text { BARI } \\
\text { Begun-6 }\end{array}$ & HRC, BARI & $\mathrm{P}_{3}$ & $\begin{array}{l}\text { Fruit is oval, straight and light green uniform color. Plant height is medium with } \\
\text { intermediate growth habit and moderately spreading with purplish green look. } \\
\text { Flower bluish violet color. Fruit position on the plant is semi-pendant. Average } \\
\text { fruit weight is } 121.56 \mathrm{~g} \text {, number of fruit per plant is } 2.99 \text { and yield/plant is } 359.55 \mathrm{~g}\end{array}$ \\
\hline SM006 & $\begin{array}{c}\text { BARI } \\
\text { Begun-8 }\end{array}$ & HRC, BARI & $\mathrm{P}_{4}$ & $\begin{array}{l}\text { Fruit is long, snaked shaped and deep purple uniform color. Plant height is high } \\
\text { with intermediate growth habit and moderately spreading greenish purplish look. } \\
\text { Flower bluish violet color. Fruit position on the plant is pendant. Average fruit } \\
\text { weight is } 48.65 \mathrm{~g} \text {, number of fruit per plant is } 7.01 \text { and yield/plant is } 341.03 \mathrm{~g}\end{array}$ \\
\hline SM024 & D 68 & PGRC, BARI & $\mathrm{P}_{5}$ & $\begin{array}{l}\text { Fruit is oblong, slight curved and green stripe color. Plant growth habit is upright in } \\
\text { nature. Plant is high with moderately spreading with light green look. Flower bluish } \\
\text { violet color. Fruit position on the plant is semi-pendant. Average fruit weight } \\
\text { is } 68.42 \mathrm{~g} \text {, number of fruit per plant is } 5.66 \text { and yield/plant is } 386.80 \mathrm{~g}\end{array}$ \\
\hline SM034 & D 79 & PGRC, BARI & $\mathrm{P}_{6}$ & $\begin{array}{l}\text { Fruit is oblong, Straight/slight curved and purplish grey color (light stripe). Plant } \\
\text { growth habit is intermediate in nature. Plant is high with moderately spreading with } \\
\text { light green look. Flower bluish violet color. Fruit position on the plant is pendant. } \\
\text { Average fruit weight is } 40.77 \mathrm{~g} \text {, number of fruit per plant is } 16.24 \text { and yield/plant is } \\
661.12 \mathrm{~g}\end{array}$ \\
\hline SM057 & $\mathrm{BD} 2840$ & PGRC, BARI & $\mathrm{P}_{7}$ & $\begin{array}{l}\text { Fruit is round, straight and Pale green mottle color. Plant growth habit is prostrate } \\
\text { in nature. Plant is dwarf with low spreading purplish look. Flower bluish violet } \\
\text { color. Fruit position on the plant is pendant. Average fruit weight is } 52.23 \mathrm{~g} \text {, } \\
\text { number of fruit per plant is } 10.10 \text { and yield/plant is } 526.11 \mathrm{~g}\end{array}$ \\
\hline SM067 & $\begin{array}{c}\text { Satkhira } \\
\text { Local }\end{array}$ & Jessore & $\mathrm{P}_{8}$ & $\begin{array}{l}\text { Fruit is round, straight and light green uniform color. Plant growth habit is } \\
\text { intermediate in nature. Plant is medium high with moderately spreading light green } \\
\text { look. Flower bluish violet color. Fruit position on the plant is semi-pendant. Very } \\
\text { few to few prickles presence on both calyx and pedicel of both flower and fruit. } \\
\text { Average fruit weight is } 130.80 \mathrm{~g} \text {, number of fruit per plant is } 3.97 \text { and yield/plant is } \\
512.00 \mathrm{~g}\end{array}$ \\
\hline
\end{tabular}

Table 1. Salient features of eight selected parental eggplant genotypes grown in summer 

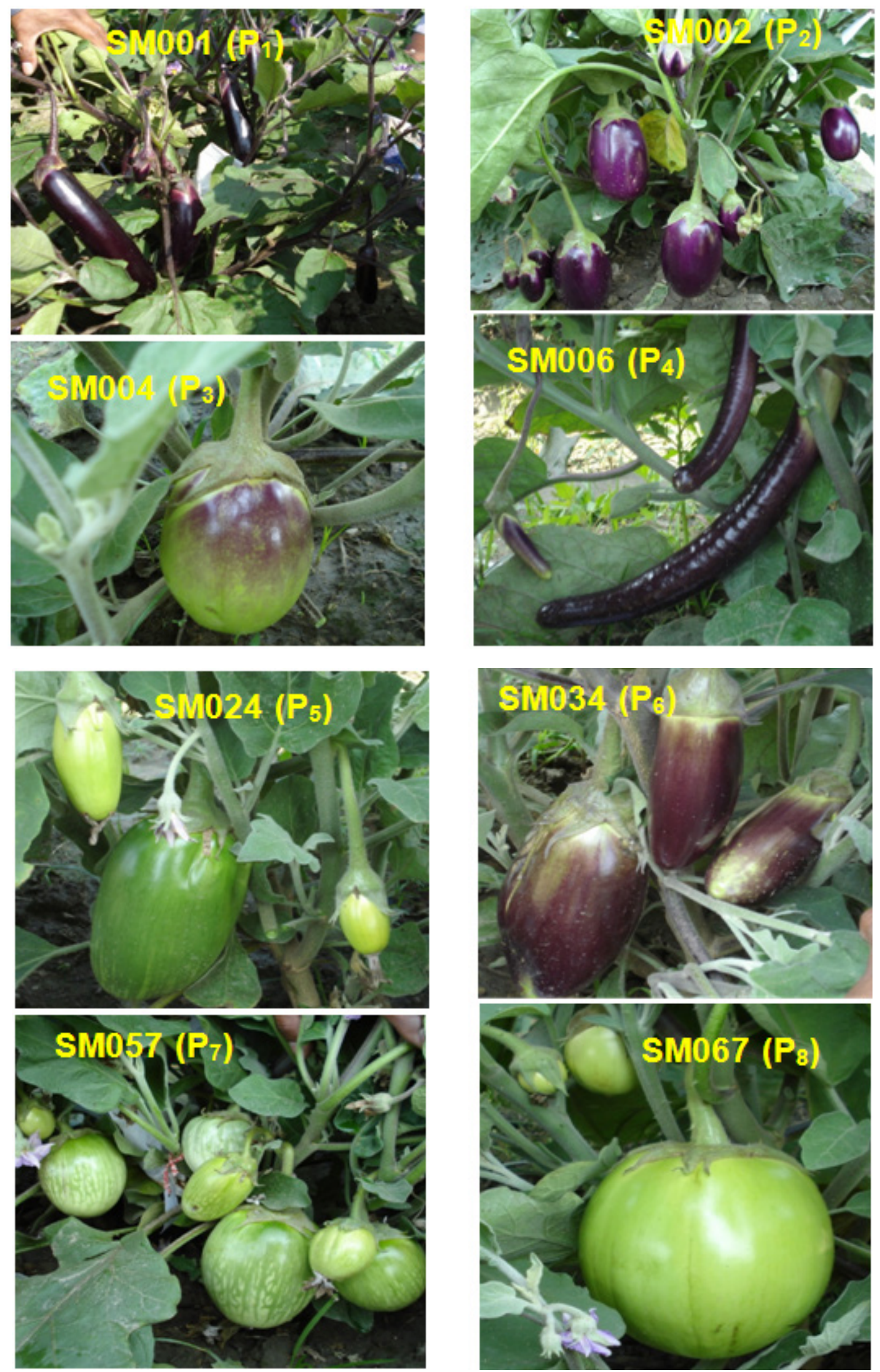

Figure 1. Fruit bearing plants of 8 selected eggplant genotypes for summer. 


\section{Results and Discussion}

The GCA effects represent the additive nature of gene action. Besides, per se performance of the parent, nature of gene action for controlling the concerned character may also be considered as a guide to select the parent. Depending upon a character, a parent with higher positive or negative significant effects is considered as a better parent for creating high yielding specific combination. The analysis of variance and the estimates of GCA effects for different characters of eight parents and the SCA effects of 28 crosses for the same characters are presented in table 2 to 8 and discussed under the following headings:

\section{Combining ability variances}

From table 2 it was revealed that the analysis of variance for combining ability (both GCA and SCA) were found highly significant for all the characters studied. Table 2 indicated the presence of both additive and non-additive genetic variance in the populations for the expression of these characters. The GCA variances were higher in magnitude than the SCA variances for all the characters indicated the predominance of additive gene effects for these characters. Rashid et al.[11] and Rahman[10] also reported both additive and non-additive effects for these characters. Besides, the predominance of additive gene effects for these characters was observed by Rahman [10] in eggplant.

\section{Combining ability effects}

Days to first harvest

Days to first harvest is more important trait for obtaining the early yield in eggplant. Combining ability (GCA and SCA) variances for days to first harvest were highly significant indicated the presence of both additive and non-additive gene for this trait. Moreover, the higher magnitude of GCA variance than SCA represented the predominance of additive gene action (Table 2). Additive genetic variance for early harvest and predominance of additive genetic variance for controlling this trait in eggplant was also reported by Rahman[10]. On the other hand, non-additive genetic variance was reported by Kumar and Ram[7].

The estimate of GCA effects of eight parents for days to first harvest presented in table 3 revealed that among the parents the highest positive and significant GCA effect was provided by $\mathrm{P}_{3}\left(5.25^{* *}\right)$ followed by $\mathrm{P}_{7}\left(0.45^{* *}\right)$. On the other hand, $\mathrm{P}_{8}\left(-2.05^{* *}\right)$ showed the highest significant negative GCA effect followed by $\mathrm{P}_{1}\left(-1.35^{* *}\right), \mathrm{P}_{4}\left(-1.35^{* *}\right), \mathrm{P}_{6}$ $\left(-0.65^{* *}\right)$ and $\mathrm{P}_{5}\left(-0.25^{* *}\right)$. Therefore, the parent $\mathrm{P}_{8}, \mathrm{P}_{1}, \mathrm{P}_{4}$ and $\mathrm{P}_{6}$ were the best general combiner for promoting early harvest in eggplant. Rahman[10] also reported some good general combiners for early harvest in eggplant.

From table 3 it was found that the highest significant positive SCA effect was provided by the cross $\mathrm{P}_{7} \times \mathrm{P}_{8}$ $\left(8.66^{* *}\right)$ followed by $\mathrm{P}_{1} \times \mathrm{P}_{4}\left(6.76^{* *}\right), \mathrm{P}_{1} \times \mathrm{P}_{5}\left(5.66^{* *}\right)$ and $\mathrm{P}_{1} \times \mathrm{P}_{3}\left(3.16^{* *}\right)$ for days to $1^{\text {st }}$ harvest. On the other hand, the highest negative significant SCA effects was provided by the cross combination $\mathrm{P}_{5} \times \mathrm{P}_{8}(-7.64 * *)$ followed by $\mathrm{P}_{1} \times \mathrm{P}_{8}$ $(-6.54 * *), \mathrm{P}_{3} \times \mathrm{P}_{5}\left(-5.94^{* *}\right), \mathrm{P}_{3} \times \mathrm{P}_{4}\left(-4.84^{* *}\right), \mathrm{P}_{4} \times \mathrm{P}_{8}$ $(-4.54 * *), \mathrm{P}_{4} \times \mathrm{P}_{6}(-1.94 * *), \mathrm{P}_{3} \times \mathrm{P}_{7}(-1.64 * *), \mathrm{P}_{2} \times \mathrm{P}_{7}$ $(-1.34 * *), \mathrm{P}_{5} \times \mathrm{P}_{7}(-1.14 * *), \mathrm{P}_{6} \times \mathrm{P}_{7}(-0.74 * *)$. Rahman[10] also reported earliness in some crosses in eggplant.

Table 2. Analysis of Variance for combining ability of plant and flowering characters in eggplant during summer

\begin{tabular}{c|c|c|c|c|c|c|c}
\hline \multirow{2}{*}{$\begin{array}{c}\text { Source of } \\
\text { variation }\end{array}$} & DF & \multicolumn{7}{|c|}{ Mean sum of squares } \\
\cline { 3 - 8 } & & $\begin{array}{c}\text { Days to } 1^{\text {st }} \\
\text { harvest }\end{array}$ & Fruit length & Fruit breadth & Fruit weight & Fruit/ plant & Yield/plant \\
\hline GCA & 7 & $51.57^{* *}$ & $5160.91^{* *}$ & $1117.66^{* *}$ & $5150.461^{* *}$ & $327.67^{* *}$ & $335083.44^{* *}$ \\
SCA & 28 & $15.82^{* *}$ & $172.17^{* *}$ & $66.70^{* *}$ & $461.96^{* *}$ & $80.48^{* *}$ & $198687.00^{* *}$ \\
Error & 70 & 0.09 & 63.28 & 9.44 & 0.72 & 0.12 & 261.6 \\
\hline
\end{tabular}

Table 3. Estimates of combining ability effects for days to $1^{\text {st }}$ harvest in eggplant for summer and summer rainy season cultivation

\begin{tabular}{|c|c|c|c|c|c|c|c|c|}
\hline \multirow{2}{*}{ Parents } & \multicolumn{7}{|c|}{ SCA } & \multirow{2}{*}{ GCA } \\
\hline & $\mathrm{P}_{2}$ & $\mathrm{P}_{3}$ & $\mathrm{P}_{4}$ & $\mathrm{P}_{5}$ & $\mathrm{P}_{6}$ & $\mathrm{P}_{7}$ & $\mathrm{P}_{8}$ & \\
\hline $\mathrm{P}_{1}$ & 0.46 & $3.16^{* *}$ & $6.76^{* *}$ & $5.66^{* *}$ & $1.06 * *$ & -0.04 & $-6.54 * *$ & $-1.35 * *$ \\
\hline $\mathrm{P}_{2}$ & & $1.86^{* *}$ & 0.46 & $-0.64 *$ & -0.24 & $-1.34 * *$ & $1.16^{* *}$ & -0.05 \\
\hline $\mathrm{P}_{3}$ & & & $-4.84 * *$ & $-5.94 * *$ & $-0.54^{*}$ & $-1.64 * *$ & $0.86^{* *}$ & $5.25^{* *}$ \\
\hline $\mathrm{P}_{4}$ & & & & $0.66^{* *}$ & $-1.94 * *$ & -0.04 & $-4.54 * *$ & $-1.35 * *$ \\
\hline $\mathrm{P}_{5}$ & & & & & -0.04 & $-1.14^{* *}$ & $-7.64 * *$ & $-0.25 * *$ \\
\hline $\mathrm{P}_{6}$ & & & & & & $-0.74 * *$ & $1.76^{* *}$ & $-0.65 * *$ \\
\hline $\mathrm{P}_{7}$ & & & & & & & $8.66^{* *}$ & $0.45^{* *}$ \\
\hline $\mathrm{P}_{8}$ & & & & & & & & $-2.05 * *$ \\
\hline SE (Sij) & & & & 0.24 & & & & \\
\hline SE (Gi) & & & & & & & & 0.09 \\
\hline $\mathrm{CD}(.05)$ & & & & 0.48 & & & & 0.18 \\
\hline $\mathrm{CD}(.01)$ & & & & 0.64 & & & & 0.24 \\
\hline
\end{tabular}

* Significant at $5 \%$ and $* *$ Significant at $1 \%$ level of probability 
Table 4. Estimates of combining ability effects for fruit length in eggplant during summer

\begin{tabular}{|c|c|c|c|c|c|c|c|c|}
\hline \multirow{2}{*}{ Parents } & \multicolumn{7}{|c|}{ SCA } & \multirow{2}{*}{ GCA } \\
\hline & $\mathrm{P}_{2}$ & $\mathrm{P}_{3}$ & $\mathrm{P}_{4}$ & $\mathrm{P}_{5}$ & $\mathrm{P}_{6}$ & $\mathrm{P}_{7}$ & $\mathrm{P}_{8}$ & \\
\hline $\mathrm{P}_{1}$ & 10.15 & -5.84 & 11.49 & -1.35 & -2.04 & $12.53^{*}$ & $-22.27 * *$ & 3.05 \\
\hline $\mathrm{P}_{2}$ & & -0.29 & $13.75^{*}$ & -7.66 & 12.44 & 2.08 & $-23.28 * *$ & $-16.21^{* *}$ \\
\hline $\mathrm{P}_{3}$ & & & 5.16 & 3.52 & 4.75 & 0.31 & 6.02 & $-6.62 * *$ \\
\hline $\mathrm{P}_{4}$ & & & & -5.54 & $24.68 * *$ & $-26.63 * *$ & -5.66 & $52.45^{* *}$ \\
\hline $\mathrm{P}_{5}$ & & & & & -5.85 & $19.31 * *$ & 2.53 & 2.09 \\
\hline $\mathrm{P}_{6}$ & & & & & & -6.65 & $14.92 *$ & -3.14 \\
\hline $\mathrm{P}_{7}$ & & & & & & & 9.24 & $-19.83^{* *}$ \\
\hline $\mathrm{P}_{8}$ & & & & & & & & $-11.79^{* *}$ \\
\hline SE (Sij) & & & & 6.28 & & & & \\
\hline SE (Gi) & & & & & & & & 2.35 \\
\hline $\mathrm{CD}(.05)$ & & & & 12.43 & & & & 4.66 \\
\hline $\mathrm{CD}(.01)$ & & & & 16.44 & & & & 6.17 \\
\hline
\end{tabular}

* Significant at $5 \%$ and ** Significant at $1 \%$ level of probability

\section{Fruit length}

Combining ability (GCA and SCA) variances for fruit length were highly significant indicated the presence of both additive and non-additive gene for this trait. Moreover, the higher magnitude of GCA variance than SCA represented the predominance of additive gene action (Table 2). Additive and non-additive genetic variance and predominance of additive genetic variance for controlling fruit length in eggplant was also reported by Rahman[10] which were the agreement with the present findings. Singh and Mital[15] reported additive gene action; while Gopinath and Madalageri[2] reported non-additive gene action for controlling fruit length in eggplant.

From table 4 it was found that among the parents the highest positive and significant GCA effect was provided by $\mathrm{P}_{4}\left(52.45^{* *}\right)$ for fruit length. Other parent like $\mathrm{P}_{1}(3.05)$ and $\mathrm{P}_{5}$ (2.09) also exhibited positive GCA effects but not significant. On the contrary, the highest significant negative GCA effect was provided by other genotypes. Therefore, the parent $\mathrm{P}_{4}$ was the best general combiner for fruit length in eggplant. Kumar and Ram[7] and Rahman[10] also reported some good general combiners for fruit length in eggplant.

From table 4 it was revealed that the highest significant positive SCA effect was provided by the cross $\mathrm{P}_{4} \times \mathrm{P}_{6}$ (24.68**) followed by $\mathrm{P}_{5} \times \mathrm{P}_{7}(19.31 * *), \mathrm{P}_{6} \times \mathrm{P}_{8}(14.92 * *)$ and $\mathrm{P}_{2} \times \mathrm{P}_{4}\left(13.75^{* *}\right), \mathrm{P}_{1} \times \mathrm{P}_{7}\left(12.53^{* *}\right)$ indicated the heterotic performance of fruit length over the mean of their parents. While, the highest negative significant SCA effects was provided by the cross combinations $\mathrm{P}_{4} \times \mathrm{P}_{7}\left(-26.63^{* *}\right)$ followed by $\mathrm{P}_{1} \times \mathrm{P}_{8}\left(-22.27^{* *}\right)$, indicated the decreasing of fruit length over the mean of their parents. Ingale and Patil[5] and Rahman[10] also reported hybrid performance in some crosses in eggplant.

\section{Fruit breadth}

The GCA and SCA variances for fruit breadth were highly significant (Table 2) indicated the presence of both additive and non-additive effects for this trait. Moreover, the higher magnitude of GCA variance than SCA represented the predominance of additive gene action. Additive and non-additive genetic variance and predominance of additive genetic variance for controlling fruit length in eggplant was also reported by Rahman[10] which corroborated to the present findings.

Among the parents the highest positive and significant GCA effect was provided by $\mathrm{P}_{8}\left(15.81^{* *}\right)$ followed by $\mathrm{P}_{3}\left(15.39^{* *}\right)$ whereas $\mathrm{P}_{7}(0.47)$ provided non-significant positive GCA effect (Table 5). On the other hand, the highest significant negative GCA effect was provided by the parent $\mathrm{P}_{5}\left(-11.46^{* *}\right)$ followed by $\mathrm{P}_{1}\left(-10.21^{* *}\right), \mathrm{P}_{6}\left(-7.50^{* *}\right)$. Therefore, the parent $\mathrm{P}_{8}$ and $\mathrm{P}_{3}$ were the best general combiner for fruit breadth in eggplant. Kumar and Ram[7] and Rahman[10] also reported some good general combiners for fruit breadth in eggplant.

Table 5 revealed that among the crosses 16 crosses showed positive SCA values. Among these the highest significant positive SCA effect was provided by the cross $\mathrm{P}_{2} \times \mathrm{P}_{3}(10.32 * *)$ followed by $\mathrm{P}_{4} \times \mathrm{P}_{6}\left(8.65^{* *}\right), \mathrm{P}_{7} \times \mathrm{P}_{8}\left(\left(8.10^{* *}\right), \mathrm{P}_{5} \times \mathrm{P}_{8}\left(6.81^{* *}\right)\right.$, $\mathrm{P}_{2} \times \mathrm{P}_{7}\left(6.72^{* *}\right), \mathrm{P}_{1} \times \mathrm{P}_{6}(6.34 * *)$, and $\mathrm{P}_{3} \times \mathrm{P}_{6}\left(5.22^{* *}\right)$ indicating the heterotic performance of fruit breadth over the mean of their parents. On the other hand, the highest negative significant SCA effects was provided by the cross combinations $\mathrm{P}_{2} \times \mathrm{P}_{8}\left(-28.25^{* *}\right)$ followed by $\mathrm{P}_{3} \times \mathrm{P}_{4}\left(-10.26^{* *}\right), \mathrm{P}_{5} \times \mathrm{P}_{6}$ $(-7.39 * *) \mathrm{P}_{1} \times \mathrm{P}_{8}(-12.04 * *)$, indicating the decreasing of fruit breadth over the mean of their parents. Prakash et al. [8], Prasath et al.[9] and Rahman[10] also reported a good specific combination for fruit diameter in eggplant. 
Table 5. Estimates of combining ability effects for fruit breadth in eggplant during summer

\begin{tabular}{|c|c|c|c|c|c|c|c|c|}
\hline \multirow{2}{*}{ Parents } & \multicolumn{7}{|c|}{ SCA } & \multirow{2}{*}{ GCA } \\
\hline & $\mathrm{P}_{2}$ & $\mathrm{P}_{3}$ & $\mathrm{P}_{4}$ & $\mathrm{P}_{5}$ & $\mathrm{P}_{6}$ & $\mathrm{P}_{7}$ & $\mathrm{P}_{8}$ & \\
\hline $\mathrm{P}_{1}$ & 1.92 & 3.36 & 1.05 & -3.77 & $6.34 *$ & 1.35 & $-12.04 * *$ & $-10.21 * *$ \\
\hline $\mathrm{P}_{2}$ & & $10.32 * *$ & 3.94 & -0.03 & -3.59 & $6.72 * *$ & $-28.25 * *$ & -1.52 \\
\hline $\mathrm{P}_{3}$ & & & $-10.26^{* *}$ & -3.94 & $5.22 *$ & -2.04 & 0.25 & $15.39 * *$ \\
\hline $\mathrm{P}_{4}$ & & & & 2.34 & $8.65 * *$ & -3.50 & 2.58 & $-11.46^{* *}$ \\
\hline $\mathrm{P}_{5}$ & & & & & $-7.39 * *$ & 4.32 & $6.81 * *$ & -0.97 \\
\hline $\mathrm{P}_{6}$ & & & & & & -3.50 & -2.21 & $-7.50 * *$ \\
\hline $\mathrm{P}_{7}$ & & & & & & & $8.10 * *$ & 0.47 \\
\hline $\mathrm{P}_{8}$ & & & & & & & & $15.81 * *$ \\
\hline SE (Sij) & & & & & 2.42 & & & \\
\hline SE (Gi) & & & & & & & & 0.91 \\
\hline $\mathrm{CD}(.05)$ & & & & & 4.80 & & & 1.80 \\
\hline $\mathrm{CD}(.01)$ & & & & & 6.35 & & & 2.38 \\
\hline
\end{tabular}

* Significant at $5 \%$ and $* *$ Significant at $1 \%$ level of probability

Table 6. Estimates of combining ability effects for fruit weight in eggplant during summer

\begin{tabular}{|c|c|c|c|c|c|c|c|c|}
\hline \multirow{2}{*}{ Parents } & \multicolumn{7}{|c|}{ SCA } & \multirow{2}{*}{ GCA } \\
\hline & $\mathrm{P}_{2}$ & $\mathrm{P}_{3}$ & $\mathrm{P}_{4}$ & $\mathrm{P}_{5}$ & $\mathrm{P}_{6}$ & $\mathrm{P}_{7}$ & $\mathrm{P}_{8}$ & \\
\hline $\mathrm{P}_{1}$ & $11.43 * *$ & $-43.29 * *$ & $10.36^{* *}$ & $-12.99 * *$ & $1.60^{*}$ & $23.96^{* *}$ & $-8.24 * *$ & $-26.78 * *$ \\
\hline $\mathrm{P}_{2}$ & & $-36.52 * *$ & $18.8^{* *}$ & $2.65^{* *}$ & $20.71 * *$ & 0.03 & $-54.84 * *$ & $-24.71 * *$ \\
\hline $\mathrm{P}_{3}$ & & & $-20.72 * *$ & $6.85^{* *}$ & $26.59 * *$ & $-16.22 * *$ & $29.91 * *$ & $25.13 * *$ \\
\hline $\mathrm{P}_{4}$ & & & & 1.13 & $11.79 * *$ & $-6.85^{* *}$ & $-4.66^{* *}$ & $-11.11 * *$ \\
\hline $\mathrm{P}_{5}$ & & & & & $-17.25 * *$ & $7.45^{* *}$ & $18.31 * *$ & $8.17 * *$ \\
\hline $\mathrm{P}_{6}$ & & & & & & $-13.00 * *$ & $-11.88^{* *}$ & $-6.92 * *$ \\
\hline $\mathrm{P}_{7}$ & & & & & & & $-8.92 * *$ & $-1.28 * *$ \\
\hline $\mathrm{P}_{8}$ & & & & & & & & 37.50 ** \\
\hline SE (Sij) & & & & 0.67 & & & & \\
\hline $\mathrm{SE}(\mathrm{Gi})$ & & & & & & & & 0.25 \\
\hline $\mathrm{CD}(.05)$ & & & & 1.34 & & & & 0.50 \\
\hline $\mathrm{CD}(.01)$ & & & & 1.78 & & & & 0.67 \\
\hline
\end{tabular}

* Significant at $5 \%$ and $* *$ Significant at $1 \%$ level of probability

\section{Fruit weight}

The mean squares due to GCA and SCA estimates for fruit weight were highly significant (Table 2) indicated the presence of both additive and non-additive gene action for this trait. Moreover, the higher magnitude of GCA than SCA represented the predominance of additive gene action. Additive and non-additive genetic variance and predominance of additive genetic variance for controlling fruit weight in eggplant was also reported by Rahman[10], which corroborated to the present findings.

From table 6 it was revealed that among the parents the highest positive and significant GCA effect was provided by $\mathrm{P}_{8}\left(37.50^{* *}\right)$ followed by $\mathrm{P}_{3}\left(25.13^{* *}\right)$ and $\mathrm{P}_{5}\left(8.17^{* *}\right)$ for individual fruit weight. Conversely, the highest significant negative GCA effect was provided by the parent $\mathrm{P}_{1}$ $(-26.78 * *)$ followed by $\mathrm{P}_{2}(-24.71 * *)$. Therefore, the parent $\mathrm{P}_{8}$ was the best general combiner followed by $\mathrm{P}_{3}$ and $\mathrm{P}_{5}$ for fruit weight in eggplant. These three parents could be used for improvement of fruit weight. Rahman[10] also reported some good general combiners for fruit weight in eggplant.

From table 6 it was also revealed that among the crosses 18 showed positive SCA values. Among them the highest significant positive SCA effect was provided by the cross $\mathrm{P}_{3}$ x $\mathrm{P}_{8}\left(29.91^{* *}\right)$ followed by $\mathrm{P}_{3} \times \mathrm{P}_{6}(26.59 * *), \mathrm{P}_{1} \times \mathrm{P}_{7}$ (23.96**), $\mathrm{P}_{2} \times \mathrm{P}_{6}(20.71 * *), \mathrm{P}_{2} \times \mathrm{P}_{4}(18.80 * *), \mathrm{P}_{5} \times \mathrm{P}_{8}$ ((18.31**), $\mathrm{P}_{4} \times \mathrm{P}_{6}(11.79 * *), \mathrm{P}_{1} \times \mathrm{P}_{2}(11.43 * *), \mathrm{P}_{1} \times \mathrm{P}_{4}$ $\left(10.36^{* *}\right) \mathrm{P}_{5} \times \mathrm{P}_{7}\left(7.45^{*}\right), \mathrm{P}_{3} \times \mathrm{P}_{5}\left(6.85^{* *}\right)$, and $\mathrm{P}_{2} \times \mathrm{P}_{5}$ $\left(2.65^{* *}\right)$, indicating the heterotic performance of fruit weight over the mean of their parents. On the other hand, the highest negative significant SCA effects was provided by the cross combinations $\mathrm{P}_{2} \times \mathrm{P}_{8}(-54.84 * *)$ followed by $\mathrm{P}_{1} \times \mathrm{P}_{3}$ $(-43.29 * *), \mathrm{P}_{2} \times \mathrm{P}_{3}(-36.52 * *)$, indicating the decreasing of fruit weight over the mean of their parents. Hence, the crosses $\mathrm{P}_{3} \times \mathrm{P}_{8}, \mathrm{P}_{3} \times \mathrm{P}_{6}, \mathrm{P}_{1} \times \mathrm{P}_{7}, \mathrm{P}_{2} \times \mathrm{P}_{6}$, and $\mathrm{P}_{5} \times \mathrm{P}_{8}, \mathrm{P}_{2} \times \mathrm{P}_{4}$, 
$\mathrm{P}_{4} \times \mathrm{P}_{6}, \mathrm{P}_{1} \times \mathrm{P}_{2}$ and $\mathrm{P}_{1} \times \mathrm{P}_{4}$ could be selected for improvement of fruit weight. Prasath et al.[9] and Rahman[10] also reported some hybrid as good specific combiner for fruit weight in eggplant.

\section{Fruits per plant}

From table 2 it was found that the mean squares due to GCA and SCA estimates for number of fruit/plant were highly significant indicating the presence of both additive and non-additive gene action for this trait. Moreover, the higher magnitude of GCA than SCA represented the predominance of additive gene action for this trait. Additive and non-additive genetic variance and predominance of additive genetic variance for controlling number of fruit/plant in eggplant was also reported by Kumar and Ram[7] and Rahman[10].

From table 7 it was found that among the parents the highest positive and significant GCA effect was provided by $\mathrm{P}_{1}\left(11.25^{* *}\right)$ followed by $\mathrm{P}_{2}\left(4.59^{* *}\right)$ and $\mathrm{P}_{6}\left(2.01^{* *}\right)$ for number of fruits per plant. On the other hand, the highest significant negative GCA effect was provided by the parent $\mathrm{P}_{5}\left(-5.37^{* *}\right)$ followed by $\mathrm{P}_{8}$ and $\mathrm{P}_{3}\left(-4.78^{* *}\right.$ and $-4.52^{* *}$ respectively). Therefore, the parent $P_{1}$ was the best general combiner followed by $\mathrm{P}_{2}$ and $\mathrm{P}_{6}$ for promoting the number of fruits per plant in eggplant. These three parents could be used for improvement of number of fruits per plant. Kumar et al.[6] and Rahman[10] also reported some good general combiners for number of fruits per plant in eggplant.

From table 7 it was revealed that among the crosses 14 showed positive SCA values for number of fruits per plant. Among these the highest significant positive SCA effect was provided by the cross $\mathrm{P}_{1} \times \mathrm{P}_{6}\left(37.44^{* *}\right)$ followed by $\mathrm{P}_{4} \times \mathrm{P}_{7}$ (7.25**), $\mathrm{P}_{2} \times \mathrm{P}_{7}(7.04 * *), \mathrm{P}_{2} \times \mathrm{P}_{8}\left(6.61^{* *}\right), \mathrm{P}_{2} \times \mathrm{P}_{3}\left(6.43^{* *}\right)$, $\mathrm{P}_{1} \times \mathrm{P}_{3}\left(4.76^{* *}\right)$ and $\mathrm{P}_{5} \times \mathrm{P}_{7}\left(3.93^{* *}\right), \mathrm{P}_{5} \times \mathrm{P}_{8}\left(2.36^{* *}\right), \mathrm{P}_{2} \mathrm{x}$ $\mathrm{P}_{4}\left(2.28^{* *}\right), \mathrm{P}_{4} \times \mathrm{P}_{8}\left(2.25^{* *}\right), \mathrm{P}_{4} \times \mathrm{P}_{5}\left(1.82^{* *}\right)$, indicating that these crosses produced more number of fruits per plant than the means of their parents. On the other hand, the highest negative significant SCA effects was provided by the cross combinations $\mathrm{P}_{2} \times \mathrm{P}_{6}\left(-13.11^{* *}\right)$ followed by $\mathrm{P}_{1} \times \mathrm{P}_{7}$ $(-11.30 * *)$ and $\mathrm{P}_{1} \times \mathrm{P}_{7}\left(-8.70^{* *}\right)$, indicating the decreasing of number of fruit per plant over the mean of their parents. Thus, the crosses $\mathrm{P}_{1} \times \mathrm{P}_{6}, \mathrm{P}_{4} \times \mathrm{P}_{7}, \mathrm{P}_{2} \times \mathrm{P}_{7}, \mathrm{P}_{2} \times \mathrm{P}_{8}, \mathrm{P}_{2} \times \mathrm{P}_{3}, \mathrm{P}_{1} \times \mathrm{P}_{3}, \mathrm{P}_{5}$ $\mathrm{x}_{7}$, could be used for improvement of number of fruits per plant. Rahman[10] also reported some superior hybrids as good specific combination for number of fruits per plant in eggplant.

Table 7. Estimates of combining ability effects for fruits per plant in eggplant during summer

\begin{tabular}{|c|c|c|c|c|c|c|c|c|}
\hline \multirow{2}{*}{ Parents } & \multicolumn{7}{|c|}{ SCA } & \multirow{2}{*}{ GCA } \\
\hline & $\mathrm{P}_{2}$ & $\mathrm{P}_{3}$ & $\mathrm{P}_{4}$ & $\mathrm{P}_{5}$ & $\mathrm{P}_{6}$ & $\mathrm{P}_{7}$ & $\mathrm{P}_{8}$ & \\
\hline $\mathrm{P}_{1}$ & -0.23 & $4.76^{* *}$ & $-4.14 * *$ & $-7.22 * *$ & $37.44 * *$ & $-11.30 * *$ & $-8.70 * *$ & $11.25 * *$ \\
\hline $\mathrm{P}_{2}$ & & $6.43 * *$ & $2.28 * *$ & $-0.72 * *$ & $-13.11 * *$ & $7.04 * *$ & $6.61 * *$ & $4.59^{* *}$ \\
\hline $\mathrm{P}_{3}$ & & & $-0.70^{*}$ & 0.11 & $-3.50 * *$ & $-2.92 * *$ & 0.40 & $-4.52 * *$ \\
\hline $\mathrm{P}_{4}$ & & & & $1.82 * *$ & $-1.88^{* *}$ & $7.25 * *$ & $2.25 * *$ & $-2.09 * *$ \\
\hline $\mathrm{P}_{5}$ & & & & & $-0.82 * *$ & $3.93 * *$ & $2.36^{* *}$ & $-5.37 * *$ \\
\hline $\mathrm{P}_{6}$ & & & & & & $-4.28 * *$ & 0.42 & $2.01 * *$ \\
\hline $\mathrm{P}_{7}$ & & & & & & & $-1.82 * *$ & $-1.07 * *$ \\
\hline $\mathrm{P}_{8}$ & & & & & & & & $-4.78^{* *}$ \\
\hline SE (Sij) & & & & 0.27 & & & & \\
\hline SE (Gi) & & & & & & & & 0.10 \\
\hline $\mathrm{CD}(.05)$ & & & & 0.54 & & & & 0.20 \\
\hline $\mathrm{CD}(.01)$ & & & & 0.71 & & & & 0.27 \\
\hline
\end{tabular}

* Significant at $5 \%$ and ** Significant at $1 \%$ level of probability

Table 8. Estimates of combining ability effects for yield/plant in eggplant during summer

\begin{tabular}{|c|c|c|c|c|c|c|c|c|}
\hline \multirow{2}{*}{ Parents } & \multicolumn{7}{|c|}{ SCA } & \multirow{2}{*}{ GCA } \\
\hline & $\mathrm{P}_{2}$ & $\mathrm{P}_{3}$ & $\mathrm{P}_{4}$ & $\mathrm{P}_{5}$ & $\mathrm{P}_{6}$ & $\mathrm{P}_{7}$ & $\mathrm{P}_{8}$ & \\
\hline $\mathrm{P}_{1}$ & $-73.91 * *$ & $-76.10 * *$ & $-94.78 * *$ & $-359.98 * *$ & $1843.45 * *$ & $-257.85^{* *}$ & $-183.74 * *$ & $327.75^{* *}$ \\
\hline $\mathrm{P}_{2}$ & & $158.45^{* *}$ & $323.22 * *$ & 19.29 & $-582.80 * *$ & $356.19^{* *}$ & $-108.21 * *$ & $88.70 * *$ \\
\hline $\mathrm{P}_{3}$ & & & $-98.39 * *$ & -8.57 & $160.70 * *$ & $78.19 * *$ & $201.93 * *$ & $-201.58 * *$ \\
\hline $\mathrm{P}_{4}$ & & & & $84.27 * *$ & -24.76 & $300.62 * *$ & $208.40^{* *}$ & $-94.81 * *$ \\
\hline $\mathrm{P}_{5}$ & & & & & $-155.80^{* *}$ & $387.33 * *$ & $251.52 * *$ & $-221.37 * *$ \\
\hline $\mathrm{P}_{6}$ & & & & & & $-404.39^{* *}$ & $186.36^{* *}$ & $129.09^{* *}$ \\
\hline $\mathrm{P}_{7}$ & & & & & & & $-195.21 * *$ & $28.50 * *$ \\
\hline $\mathrm{P}_{8}$ & & & & & & & & $-56.29 * *$ \\
\hline SE (Sij) & & & & 12.76 & & & & \\
\hline $\mathrm{SE}(\mathrm{Gi})$ & & & & & & & & 4.78 \\
\hline $\mathrm{CD}(.05)$ & & & & 25.52 & & & & 9.56 \\
\hline $\mathrm{CD}(.01)$ & & & & 33.93 & & & & 12.61 \\
\hline
\end{tabular}

* Significant at $5 \%$ and ** Significant at $1 \%$ level of probability 


\section{Yield per plant}

From table 2 it was found that the GCA and SCA variances for yield/plant were highly significant suggesting the presence of both additive and non-additive gene action for this trait. Besides, the higher magnitude of GCA compare to SCA represented the predominance of additive gene action for this trait. Additive and non-additive genetic variance and predominance of additive genetic variance for controlling yield/plant in eggplant was also supported by Kumar and Ram[7], Chadha and Hedge[1] and Rahman[10].

From table 8 it was clear that among the parents the highest positive and significant GCA effect was provided by $\mathrm{P}_{1}$ $\left(327.75^{* *}\right)$ followed by $\mathrm{P}_{6}\left(129.09^{* *}\right), \mathrm{P}_{2}\left(88.70^{* *}\right)$ and $\mathrm{P}_{7}$ $\left(28.50^{* *}\right)$ for fruit yield per plant. On the other hand, the highest significant negative GCA effect was provided by the parent $\mathrm{P}_{5}\left(-221.37^{* *}\right)$ followed by $\mathrm{P}_{3}\left(-201.58^{* *}\right)$, P4 $\left(-94.81^{* *}\right)$ and $\mathrm{P}_{8}\left(-56.29^{* *}\right)$. Therefore, the parent $\mathrm{P}_{1}$ was the best general combiner followed by $\mathrm{P}_{6}, \mathrm{P}_{2}$ and $\mathrm{P}_{7}$ for promoting the yield of fruit per plant in eggplant. These three parents could be used for improvement of fruit yield per plant. Several workers also reported some good general combiners for fruit yield per plant in eggplant $[7,1,10]$.

Table 8 revealed that among the crosses 14 showed positive SCA values. Among these the highest significant positive SCA effect was provided by the cross $\mathrm{P}_{1} \times \mathrm{P}_{6}$ (1843.45**) followed by $\mathrm{P}_{5} \times \mathrm{P}_{7}\left(387.33^{* *}\right), \mathrm{P}_{2} \times \mathrm{P}_{7}$ (356.19**), $\mathrm{P}_{2} \times \mathrm{P}_{4}(323.22 * *), \mathrm{P}_{4} \times \mathrm{P}_{7}(300.62 *), \mathrm{P}_{5} \times \mathrm{P}_{8}$ $\left(251.52^{* *}\right), \mathrm{P}_{4} \times \mathrm{P}_{8}\left(208.40^{* *}\right), \mathrm{P}_{3} \times \mathrm{P}_{8}\left(201.93^{* *}\right), \mathrm{P}_{6} \times \mathrm{P}_{8}$ (186.36**), $\mathrm{P}_{3} \times \mathrm{P}_{6}\left(160.70^{* *}\right), \mathrm{P}_{2} \times \mathrm{P}_{3}\left(158.45^{* *}\right), \mathrm{P}_{4} \times \mathrm{P}_{5}$ $\left(84.27^{* *}\right)$, and $\mathrm{P}_{3} \times \mathrm{P}_{7}\left(78.19^{* *}\right)$, indicating that these crosses produced more fruit yield per plant than the means of their parents. On the other hand, the highest negative significant SCA effects was provided by the cross combinations $\mathrm{P}_{2} \times \mathrm{P}_{6}\left(-582.80^{* *}\right)$ followed by $\mathrm{P}_{6} \times \mathrm{P}_{7}$ $\left(-404.39^{* *}\right)$, indicating the decreasing of fruit yield per plant over the mean of their parents. Thus, the crosses $\mathrm{P}_{1} \times \mathrm{P}_{6}, \mathrm{P}_{5} \times$ $\mathrm{P}_{7}, \mathrm{P}_{2} \times \mathrm{P}_{7}, \mathrm{P}_{2} \times \mathrm{P}_{4}, \mathrm{P}_{4} \times \mathrm{P}_{7}, \mathrm{P}_{5} \times \mathrm{P}_{8} \mathrm{P}_{4} \times \mathrm{P}_{8}, \mathrm{P}_{3} \times \mathrm{P}_{8}, \mathrm{P}_{6} \times \mathrm{P}_{8}$, and $\mathrm{P}_{3} \times \mathrm{P}_{6}$ could be used for improvement of fruit yield per plant. The present finding was supported by Chadha and Hedge[1] and Rahman[10].

\section{Conclusions and Recommendation}

Considering GCA effects, the parents $\mathrm{P}_{1}, \mathrm{P}_{5}, \mathrm{P}_{6}$ and $\mathrm{P}_{8}$ were considered as better general combiner for promoting early fruiting; $\mathrm{P}_{3}, \mathrm{P}_{5}$ and $\mathrm{P}_{8}$ for fruit weight; $\mathrm{P}_{1}, \mathrm{P}_{2}, \mathrm{P}_{6}$ for number of fruits per plant; $\mathrm{P}_{1}, \mathrm{P}_{6}, \mathrm{P}_{2}$ and $\mathrm{P}_{7}$ for yield per plant. Considering SCA effects, the crosses $\mathrm{P}_{1} \times \mathrm{P}_{5}, \mathrm{P}_{3} \times \mathrm{P}_{5}, \mathrm{P}_{4} \times \mathrm{P}_{6}$, $\mathrm{P}_{4} \times \mathrm{P}_{8}, \mathrm{P}_{5} \times \mathrm{P}_{7}$ and $\mathrm{P}_{5} \times \mathrm{P}_{8}$ were better for earliness; and the crosses $\mathrm{P}_{1} \times \mathrm{P}_{6}, \mathrm{P}_{5} \times \mathrm{P}_{7}, \mathrm{P}_{2} \times \mathrm{P}_{7}, \mathrm{P}_{2} \times \mathrm{P}_{4}, \mathrm{P}_{4} \times \mathrm{P}_{7}, \mathrm{P}_{4} \times \mathrm{P}_{8}, \mathrm{P}_{3} \times \mathrm{P}_{8}$, $\mathrm{P}_{5} \times \mathrm{P}_{8}, \mathrm{P}_{6} \times \mathrm{P}_{8}, \mathrm{P}_{3} \times \mathrm{P}_{6}, \mathrm{P}_{2} \times \mathrm{P}_{3}, \mathrm{P}_{4} \times \mathrm{P}_{5}, \mathrm{P}_{3} \times \mathrm{P}_{8}$ were better hybrids for improving yield per plant in eggplant. Therefore, the parents $\mathrm{P}_{1}, \mathrm{P}_{6}, \mathrm{P}_{2}$ and $\mathrm{P}_{7}$ and $\mathrm{P}_{8}$ could be considered as better parents for earliness and higher yield and the crosses
$\mathrm{P}_{1} \times \mathrm{P}_{6}, \mathrm{P}_{5} \times \mathrm{P}_{7}, \mathrm{P}_{2} \times \mathrm{P}_{7}, \mathrm{P}_{2} \times \mathrm{P}_{4}, \mathrm{P}_{4} \times \mathrm{P}_{7}, \mathrm{P}_{4} \times \mathrm{P}_{8}, \mathrm{P}_{3} \times \mathrm{P}_{8}, \mathrm{P}_{5} \times \mathrm{P}_{8}$ could be considered as promising hybrids for early fruiting and higher yield. These parents and the hybrids could be used for commercial cultivation during summer in Bangladesh.

\section{REFERENCES}

[1] M.L. Chadha, R.K. Hedge. Combining ability studies in brinjal. Indian J. Hort., Vol.46, No.1, 44-52, 1989.

[2] G. Gopinath, Madalageri. Genetics of yield and its components in brinjal (Solanum melongena L.), Haryana J. Hort. Sci., Vol.15, No.1\&2, 103-109, 1986.

[3] B. Griffing. A generalized treatment of the use of diallel cross in quantitative inheritance, Heredity, Vol.10, 13-50, 1956a.

[4] B. Griffing. Concepts of general and specific combining ability in relation to diallel crossing systems, Australian J. Biol. Sci. Vol.9, 463-493, 1956b.

[5] B.V. Ingale, S.J. Patil. Heterosis breeding in brinjal (Solanum melongena L.), PKV Res. J., Vol.21, No.1, 25-29, 1997.

[6] R. Kumar, D.N. Singh, K.K. Prashad, R. Kumar. Combining ability analysis in brinjal (Solanum melongena L.), Journal of Research, Birsha Agricultural University, Vol.8, No.1, 45-49, 1996.

[7] N. Kumar, H.H. Ram. Combining ability and gene effect analysis of quantitative characters in eggplant, Indian J. Agril. Sci., Vol.57, No.2, 89-102, 1987.

[8] K.T. Prakash, P. Shivashankar, H.R. Gowda. Line x tester analysis for combining ability in brinjal (Solanum melongena L.), Crop Research Hisar. Vol.8 No.2, 296-301, 1994.

[9] D. Prasath, S. Natarajan, S. Thamburaj. Line $\mathrm{x}$ tester analysis for heterosis in brinjal (Solanum melongena L.), Orissa J. Hort., Vol.28, No.1, 59-64, 2000.

[10] M.A. Rahman. Heterosis in eggplant, MS Thesis, Dept. of Horticulture, BSMRAU, Gazipur, Bangladesh. p. 108, 2003.

[11] M.A. Rashid, S.N. Mondol, M.S. Ahmed. S. Ahmed, D.K. Sen. Genetic Variability, combining ability estimates and hybrid vigor in eggplant (Solalanum melongena L.), Thai. J. Agric. Sci., Vol.21, 51-61, 1988.

[12] M.G. Saha, S.M. Sharifuzzaman, A. Bhawmik, K.R. Hoque, A.K.M. Amzad Hossain. Genetic analysis of flowering time in brinjal (Solanum melongena L.), Bangladesh Hort., Vol.20, No.1, 35-39, 1992.

[13] B. Singh, N. Kumar. Studies on hybrid vigor and combining ability in brinjal (Solanum melongena L.), Vegetable Science, Vol.15, No.1, 72-78, 1988.

[14] D.P. Singh, V.S.R.K. Prasad, R.P. Singh. Combining ability in eggplant, Indian J. Hort., Vol.48, No.1, 52-57, 1991.

[15] N.D. Singh, R.K. Mital. Genetics of yield and its components in eggplant, Indian J. Agril. Sci., Vol.58, 402-403, 1988 